\title{
Forum
}

PMLA invites members of the association to submit letters, printed and doublespaced, that comment on articles in previous issues or on matters of general scholarly or critical interest. The editor reserves the right to reject or edit Forum contributions and offers the PMLA authors discussed in published letters an opportunity to reply. Submissions of more than one thousand words are not considered. The journal omits titles before persons' names and discourages endnotes and works-cited lists in the Forum. Letters should be addressed to PMLA Forum, Modern Language Association, 26 Broadway, 3rd floor, New York, NY 10004-1789.

250

\section{New World Sloth}

\section{To THE Editor:}

The note on figure 4 in Richard John Ascárate's article "Have You Ever Seen a Shrunken Head? The Early Modern Roots of Ecstatic Truth in Werner Herzog's Fitzcarraldo" (122 [2007]: 483-501) asserts, "The sloth in the lower right corner is a symbol of America's historical lassitude" (491). The animal is an anteater. The sloth is a short-faced arboreal vegetarian (eating leaves, buds, and fruit) with strongly hooked claws on all four feet, admirably adapted to hanging upside down from limbs of trees but ill-adapted to ground travel. The anteater (a terrestrial animal) has a long face and long, sticky tongue (shown in van der Straet's image) adapted to trapping ants and termites. One might guess that in figure 4, the anteater has inserted its tongue into an underground ant or termite nest. The anteater's powerful forefeet with short, strong claws, suitable for breaking into ant- or termite hills, are clearly visible in the image. What allegorical meaning might be imposed on this animal is past my conjecture.

The erroneous gloss on the engraving seems hard to explain, since the sloth in figure 3 is correctly identified. The sloth lives only in South and Central America and might indeed have seemed exotic to Europeans, who would hardly be surprised to find animals like Africa's crocodiles, lions, and leopards in the Americas. Most educated Europeans would have heard of African cannibalism, however, and would probably regard New World cannibalism as deplorable (or titillating) but not strange.

The implement leaning against a tree in the lower right corner of figure 4 looks like a paddle, wooden spade, or large war club belonging to the almost naked woman sitting in her hammock. Whether tool or weapon, the instrument seems an inappropriate symbol of lassitude. But

(C) 2008 BY THE MODERN LANGUAGE ASSOCIATION OF AMERICA 
after all, given the strenuous resistance most people make to being eaten, an idle cannibal would starve. And so would a lazy anteater.

George Clark

Queen's University

\section{Reply:}

Alas, the animal in the lower right corner of Jan van der Straet's engraving is an anteater (perhaps Tamandua tetradactyla). Only a noble delicacy regarding the author's feelings, however, must have prevented George Clark from disclosing the sloth's true location. The phlegmatic beast (likely Choloepus hoffmanni) may be seen-though not easily, even in contemporary prints-on the tree farthest right, in the shadows just below the point where large branches diverge from the trunk. (Those of acute vision or abundant leisure may also notice some cannibals in the background, grilling what seem to be human limbs in a space intersected by the reciprocal gazes of the two human subjects in the foreground.)

The attribution of lassitude to the metaphoric female figure of America follows an accepted and, to this observer, reasonable interpretation of the visual evidence. That is, the naked, unarmed woman seems not merely to be sitting, as Clark maintains, but to be rising from slumber, or at least from a supine position. (Incredulous readers may wish to consult their own experience with hammocks to confirm this assertion.) The erect male European, equipped scientifically (astrolabe in hand), militarily (sword peeking out from behind), and religiopolitically (crucifix atop the banner) for conquest, has caught the lady by surprise.

Van der Straet's image does lend itself to more penetrating analysis (likewise, perhaps, the matter of the anteater's tongue), but to have included such would have taken the reader too far afield from the subject of the essay, which is, as the title intimates, Werner Herzog's film. In any event, sincerest apologies to Choloepus hoffmanni, Tamandua tetradactyla, Clark, and any other Homo sapiens who may have been disgraced, impeached, or otherwise baffled by the inadvertent misidentification.

\section{Richard John Ascárate}

Washington, DC

\section{The Anatomy of Allusion}

\section{TO THE EDITOR:}

Gregory Machacek's “Allusion” (122 [2007]: 522-36) contains useful, thought-provoking terminology. Is it possible that on rare occasions "inherently uninteresting" allusions or a "nonallusive echo" (qtd. on 530-31) might be euphemisms for a more sinister term-plagiarism?

Near the conclusion of William Styron's The Long March (1952), a novella concerning a forced march at a marine training camp, the following passage contains a troubling phraseological adaptation: "Yes, they had had it—-those eight boys-he [Lt. Culver] thought. ... In mindless slumber now, they were past caring, though diadems might drop or Doges surrender. They were ignorant of all." Styron's source is an Emily Dickinson poem (number 216 in The Complete Poems of Emily Dickinson [Boston: Little, 1960]):

$$
\begin{aligned}
& \text { Safe in their Alabaster Chambers- } \\
& \text { Untouched by Morning- } \\
& \text { And untouched by Noon- } \\
& \text { Lie the meek members of the Resurrection- } \\
& \text { Rafter of Satin - and Roof of Stone! } \\
& \text { Grand go the Years-in the crescent-above } \\
& \text { them- } \\
& \text { Worlds scoop their Arcs- } \\
& \text { And Firmaments-row- } \\
& \text { Diadems-drop-and Doges-surrender- } \\
& \text { Soundless as dots-on a Disc of Snow- }
\end{aligned}
$$

Authors establish a relation between their text and another-intertextuality-through

Emily Dickinson's poem "Safe in their Alabaster Chambers-" is reprinted by permission of the publishers and the Trustees of Amherst College from The Poems of Emily Dickinson, Thomas H. Johnson, ed., Cambridge, Mass.: The Belknap Press of Harvard University Press, Copyright (C) 1951, 1955, 1979, 1983 by the President and Fellows of Harvard College. 